\title{
Media re-education and the need to be constantly updated
}

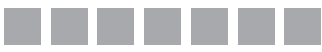 \\ Interview with Grzegorz Ptaszek \\ AGH UNIVERSitY OF SCIENCE AND TECHNOLOGY IN KRAKOW, POLAND \\ https://doi.org/10.19195/1899-5101.13.2(26).8
}

As described in the editorial of this special issue, each country has its own historical tradition and approach to media literacy. How would you describe the Polish approach?

In Poland we have actually not been talking about "media literacy" (kompetencje medialne) for a long time anymore but, instead, about "media education" (edukacja medialna). At the beginning of the 21st century, when the discussion about new literacies in the world of digital media emerged, the concept of media literacy became more popular than the notion of media education. In my opinion, the dominance of the concept media literacy resulted, among others, from quite a wrong understanding of media education as only activities within formal education and related to the critical analysis of traditional media. Today, I think that media literacy education should be perceived more broadly and not only in the strictly limited meaning of using media as well as information and communication technology (ICT) in the classroom; it also remains in connection to related research areas focusing on various aspects of media and ICT, such as communication and media studies, cultural studies, as well as the concept of lifelong learning.

As you may remember, the notion of "information" in media literacy was initially presented during the international forum organised in 2011 in Fez, Morocco, with the support of UNESCO. It was the initiative of the international community of information science researchers who were one of the first to start a discussion on searching and assessing information skills related to the Internet. They demanded that "information literacy" should be recognised as an equivalent to "media literacy", which, consequently, contributed to the dissemination of the concept of "Media and Information Literacy" (MIL). Since then, the idea of MIL has been adopted in a dozen countries around the world, mainly in those in which the national UNESCO committees have been promoting it dynamically. This also happened in Poland. 
Nevertheless, I personally think that both concepts are equally important today because media literacy (ML) and media and information literacy (MIL) are the goals of media education, or, as you say, media literacy education. Returning to your question about what distinguishes the Polish approach to MIL, I want to say that the Polish Association for Media Education, of which I am the president, has together with several entities been working for the promotion of media education in Poland. We have popularised an approach which we call "Media, Information, and Digital Literacy" (MIDL). In this approach, all key competencies - media, information, and digital ones - are just as equal and relevant. The MIDL approach underlies an assumption that nowadays the digital media environment - although it is an extremely important place for our social and individual experience - is only one of the many environments in which we operate and it can be treated as augmented communication reality. Therefore, we propose a coherent definition of media, information, and digital education, referring to all these environments. We do so in order to be able to look at this issue from a broader perspective, including technological, social, cultural, and ethical issues. Today we need such a broad, holistic view of MIL to include in it the entire complexity of both our media-mediated practices and the diverse needs (social, cultural, personal, etc.) met by using digital media. In 2019, a group of media literacy experts from different organisations and institutions prepared a publication titled "Media, Information and Digital Education Model" (MIDEM), which will be published in a few weeks in English. In this publication, we are focusing only on the classroom context and are proposing the set of professional and personal media, information, and digital literacy of teachers. Our suggestion is tailored to help effectively in including the latter group of competencies to the training of teachers. Moreover, in this publication, we are indicating specific actions that should be taken in schools and in decision-making centres and institutions responsible for education, such as local governments and HEIs (higher education institutions).

The MIDL approach reflects an ambition to include the digital competencies and learning environments in the notion of MIL. As known, it has been argued that MIL is a concept takes account the digital turn by incorporating the information literacy dimension. At the same time, your approach also represents, once again, an expansion of the concept that started with "media", was extended to encompass "information", and now, the "digital". This resonates with the most recent ideas of extended, augmented and broadened media literacy notions, for example by UNESCO to extend MIL to cover the group, community, and institution perspective instead of seeing it as a set of skills of individuals. However, extending the concept may be quite contraproductive. How do we prevent MIL from becoming too inclusive and emptied of its meaning? Do you see such a risk here? 
Yes, our MIDL approach absolutely dovetails with attempts to gain an extended, augmented, or integrated view on media education, such as the UNESCO MIL Expansion $\left(\mathrm{MIL}^{\mathrm{x}}\right)$ approach. But I feel sometimes that all media educators - academics, practitioners, and policymakers - are talking on basically the same issues but in diverging ways. Just compare how many different terms we use for the umbrella term media literacy: media literacy, media and information literacy, digital literacy, digital competences, digital skills, transmedia literacy, dynamic literacies, now MIL $^{\mathrm{x}}$ or multiliteracies. With the concept of MIDL, we wanted to underline that all key competencies are interlinked, and therefore we need to perceive them together. I think that we are looking for a term which will describe the situation in which we are living. The fact that academics build models like MIL ${ }^{\mathrm{x}}$ reflect the challenges that we have, regarding the complexity and diversity of requirements set to individuals, groups, and organisations to master media. In my opinion, this development shows that we need to redefine what MIL is, or carefully define our understandings of the term every time we use it. This is, of course, not always so easy, as many of these understandings derive from the contexts we are embedded in, and we may not even always be aware of how our understanding compares to others'.

\section{What kind of challenges do you see in putting media education into practice in the current digital landscape?}

The more media penetrate our lives, the more literate we should become, especially in using media and understanding what rules govern them. Media literacies are not given to us once and for all - we need to keep updating them. Together with my colleague, professor Agnieszka Ogonowska from the Pedagogical University of Krakow, we have described this phenomenon as media re-education. Media reeducation refers to a persistent and constant need to educate an individual whose previous competencies and knowledge about the functioning and consumption of media and ICT tools cannot be applied to the new, constantly changing reality. It is the need to design activities for the continuous improvement of media (and information, and digital) literacy in response to the challenges of modern media civilization and the fast-changing world of technology. Media re-education responds to these challenges and changes. In some aspects, this idea is related to the notion of lifelong learning because you have to learn all the time - not only how to use new tools in a technical way, but also how to efficiently make use of them in crucial aspects of your life. Let me give you an example of this media reeducation idea: If you use the Internet well on your computer, you have to learn how to use it on a mobile, too - they have different interfaces and additionally, usage practices are different as well. And the second example: computational propaganda. If you know what classic propaganda is you might have a problem with how to recognise that new one. 
Media education as an iterative process reminds me of the emergence - and the importance - of a learning-how-to-learn paradigm. It is no longer enough to take in information on media or adopt skills according to some pre-made educational or pedagogic structures, as no educational structures can entirely follow the rapid evolvement of the digital landscape. Instead, individuals must develop their own digital learning environments and discover sources to update their information. Is it somewhere in this direction that you refer to with "media reeducation"? How should formal education institutions take this paradigm into account, for example how does this apply to schools and teacher training?

Yes, I agree that our world is changing rapidly and some institutions, especially the educational ones, have difficulties in keeping up with these changes. Therefore, teachers are not well prepared for not only how to understand the new environment of digital media, but also how to use it to empower individual lives. As I have said, in our MIDL model we propose a set of skills addressing professional and personal media, information, and digital literacy of teachers, which help them to update their competencies. It is necessary because students in teacher training programmes at universities are often not prepared enough for the future working life. Last year, the Polish Association for Media Education worked hard to enable the inclusion of some key MIL standards in the teacher training curricula. We even recommended to build a separate special study path for media education, but the Ministry of Higher Education that was responsible for compiling this document refused our proposal.

In many countries with an advanced MIL policy, media education has turned out to be successful when conducted as cross-sectoral collaboration. Do you see challenges in cross-sectoral collaboration in Poland, and how could this collaboration be improved?

It's a difficult question. A successful cooperation is a result of many different factors, primarily determination, but also good relations among various stakeholders. Cross-sectoral cooperation between various stakeholders involved in activities related to the development of MIL should come from the assumption that such activities are important, necessary, and essential for the development of media awareness of the contemporary media users.

A good solution could be various coalitions or alliances forming by various institutions and organisations that can use their own resources and contacts for example, or lobbying for specific purposes. It is complicated because, in the end, everything comes down to a political will, but such efforts are made in our country. There are actually three such networks in Poland: the Media and Information Education Coalition (of which the Polish Media Education Association is a member), the Broad Agreement on Digital Skills, and the Digital Education Network COMETA. The question, of course, is how far these networks want to work together 
- sometimes they succeed, and sometimes they compete with each other. Perhaps the experiences of Sweden, Finland, or the other Baltic countries could be a guide for us on how to solve this problem. I will gladly find out what you think about it.

\section{The political climate in Poland has not lately been in favour of developing MIL. How do you assess the current situation in the country?}

I get the impression that certain areas of competencies, such as the assessment and critical understanding of media or media content, are uncomfortable to the government right now. The Polish government is the largest entity financing MIL-related activities and projects. Since 2015, when the power in Poland was changed and was taken over by the right-wing Law and Justice Party, the Ministry of Culture and National Heritage has withdrawn from the educational programme devoted to media education. The National Broadcasting Council, which is the supervising body for public broadcasters and should control whether the broadcasters implement media education policy, has completely ceased to engage in activities promoting MIL. Previously it was the leading actor in this field for a long time.

The politicisation of public media, the use of propaganda in media messages, and the use of new propaganda techniques, for example, computational propaganda, do not favour the promotion of certain MIL activities in Poland. It does not mean, of course, that the government does not support projects in this regard. For example, the Ministry of National Education, the Ministry of Digital Affairs, and the Ministry of Culture and National Heritage finance activities. However, I would say that they have more often provided financial support for educational programmes concentrating on technical skills such as coding, ICT in education, cyberbullying, privacy protection, and so on, rather than on social- or critical-thinking competencies.

Another issue is the lack of reporting on implemented projects of MIL in our country at the level of state administration, so that we could know better which areas of competencies and which social or professional groups would require greater attention. There is also no research or analysis on this topic. We blunder around and focus on competencies that we consider important at the moment. Currently, this is the case of many funded projects related to critical thinking and evaluation skills, as well as verification of information, due to the fact that we are inundated with fake news every day and politicians deliberately misinform society for their own benefits. This situation is the result of negligence by media education researchers who focused on completely different competencies - mainly on the technical ones.

\section{What are you working on right now personally?}

My interest in MIL or, more broadly, media education, is the result of my own education and experience. I graduated from psychology and linguistics, and I did my 
postdoctoral studies (in Polish, habilitation) in communication and media studies. I was one of the first researchers in Poland who, in the early 2000s, began to pay attention to the fact that the critical understanding of media and the whole environment are much more important than using media and enhancing merely technical skills.

Currently, in my research I am focusing on developing and promoting the idea that I called "media education 3.0". I have developed this idea in my latest book entitled in English, Media Education 3.0: Critical Understanding of Digital Media in the Age of Big Data and Algorithmization [Edukacja medialna 3.0: Krytyczne rozumienie mediów cyfrowych $w$ dobie Big Data I algorytmizacji]. The book was published in 2019. In the book, I discuss how new phenomena related to invisible technologies - digital data and algorithms - that are significantly modifying the contemporary media environment, also redefine media education. Media education must always adapt its area of interest to the changing reality and transformations of the media ecosystem. It was one of the fundamental principles of media education that was defined by the pioneer of media education, Len Masterman.

I am currently working on two projects related to media education 3.0, oscillating around the so-called algorithmic awareness. Algorithmic awareness can be defined as a mental state in which an individual notices the occurrence of invisible technological processes regulated by algorithms and their impact on how he or she consumes the content and experiences it. Today, many users do not realise how many spheres of their digital activities are regulated by algorithms. In the near future, due to the increasingly common services based on voice assistants - whose functioning is fully algorithmised and equipped with mechanisms of artificial intelligence - this type of literacy may turn out to be extremely important. Consider that only errors in the functioning of voice assistants show us how these types of devices can be dangerous: in December 2019, the world learnt that Alexa - Amazon's voice assistant - when asked by a female user about the functioning of a heart, decided to supplement on its own the piece of information taken from Wikipedia, encouraging this user to stab her heart. Of course, this example is quite extreme, but it also shows that we must keep updating our own knowledge of MIL.

\section{Considering MIL research in more general terms, what kind of developments do you see in the Eastern Baltic Sea region? What paths should we take in the near- est future?}

The countries around the Baltic Sea region are very diverse in terms of activities for the benefit of MIL. On the one hand, we have countries such as Sweden, Germany, and Finland, which were among the first countries in the world to understand the need to introduce a national policy for the development of MIL at the level of formal education. On the other hand, we have post-communist countries such as Poland, Lithuania, and Latvia where, due to the political system, for a long time media education was understood differently - namely, as the use of media in the 
education process. This means that the contrasts between individual countries in this geographical region are relatively big.

I honestly admit that I do not see that there would have been any specific common topics or problems associated with MIL that would have brought the countries in the Eastern Baltic Sea region together, or would particularly distinguish them. It seems to me that this is because of a limited exchange of common experiences among these countries. The low amount of cooperation and benchmarking may stem from, among other things, cultural differences; in contrast to the Scandinavian countries, the Baltic countries have different languages, and media education is often tightly connected to linguistic issues.

It would be worth considering a seminar or a conference devoted to this. Today, we are all struggling with very similar problems: an anti-immigrant discourse undermining the principles of liberal democracy that shaped the political order after World War II, homophobia, discussions about the presence of religion in the public space. These problems largely affect what and how the media talk to us. Moreover, another common problem, even if not particularly characteristic of the Baltic Sea region only, may be the platformisation of media and its impact on journalism, which will be subjected to platform logic for profit. So, maybe it's worth making us think about strengthening the cooperation within the Baltic States?

Professor Grzegorz Ptaszek was interviewed by Maarit Jaakkola.

Grzegorz Ptaszek is a communication and media studies researcher, psychologist, and linguist. He is associate professor in the Faculty of Humanities at the AGH University of Science and Technology in Krakow, Poland. He is the author of two books in Polish, titled Media Education 3.0: Critical understanding of digital media in the age of Big Data and algorithmization [Edukacja medialna 3.0: Krytyczne rozumienie mediów cyfrowych w dobie Big Data i algorytmizacji] (Jagellonian Press, 2019) and Talk Show: Honesty on the screen? [Talk show: Szczerość na ekranie?] (Wydawnictwa Akademickie i Profesjonalne, 2007). He has also co-edited several books and dozens of articles on various aspects of the media and media education. Ptaszek is also the president of the Polish Association for Media Education (www. ptem.org.pl) and a member of both the Polish Communication Association (PCA) and the European Communication Research and Education Association (ECREA). 